\title{
Primate study halted by US university
}

\section{Officials fear violent reprisals from a reinvigorated animal-rights movement.}

Administrators at Oklahoma State University (OSU) in Stillwater have abruptly cancelled an anthrax vaccine study that would have killed dozens of baboons.

The project, funded by the US National Institutes of Health (NIH) and led by Shinichiro Kurosawa of Boston University School of Medicine in Massachusetts, had been approved by the OSU animal-care committee in September and was awaiting review by the biosafety committee when OSU president Burns Hargis vetoed it in October, calling the study "controversial".

Kurosawa had hoped to use the OSU animal facility because it has the required level of biosafety containment for anthrax. "As guest scientists at OSU, we are obliged to follow their policies, and it is unfortunate that we cannot fully complete our research there at this time," Kurosawa says. Along with collaborators at the Oklahoma Medical Research Foundation in

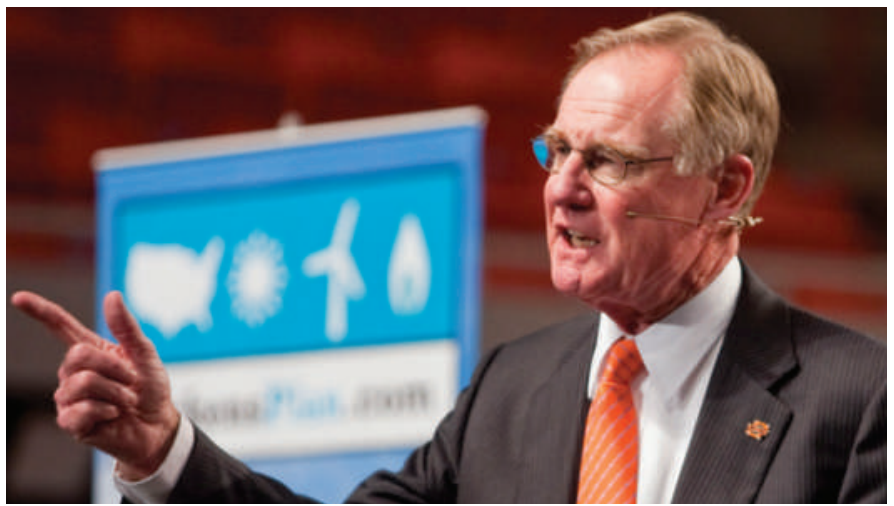

Burns Hargis has vetoed a primate study at Oklahoma State University.

oil magnate and OSU benefactor T. Boone Pickens. Madeleine Pickens had previously expressed disapproval of surgical training procedures involving animals in the university's veterinary school. Spokespeople for both Pickens and the university deny the suggestion. Hargis defended his decision in the Tulsa World newspaper, emphasizing that 124 animals could have been killed on campus.

"There are regrettably some violent acts committed by animal-rights groups," says OSU vice-president of research Stephen

Oklahoma City, the University of Oklahoma in Norman and the University of Chicago in Illinois, he planned to investigate the biochemical pathways that lead to death following anthrax infection, and to test an anthrax vaccine.

Some faculty members have suggested that the decision to cancel the study might be linked to pressure from Madeleine Pickens, the wife of
McKeever, "and the president felt we should take our breath here and not do this project just yet." McKeever says the decision does not indicate a change in institutional policy, but that future proposals for primate studies will be considered in consultation with researchers, the OSU animal-care committee and his administrators. Indeed, for several

\section{Culture clash at Australian synchrotron}

The future of Australia's biggest scientific facility, the Australian Synchrotron in Melbourne, is in question. After its director was fired and its staff went on strike in recent weeks, relations between the board that oversees the facility and the scientists who use it have broken down.

Australian and international researchers who sit on the synchrotron's Science Advisory Committee (SAC) are due to meet with board director and lawyer Catherine Walter, and have threatened to resign unless Walter herself leaves. "If the committee resigns, no eminent scientist from around the world is going to touch the Australian Synchrotron with a bargepole," says a synchrotron researcher who asked to remain anonymous.

"We have drawn a line in the sand," says committee chair Frank Larkins, of the University of Melbourne. "Of the 40-odd synchrotrons around the world, I don't think this has ever happened before." Larkins says that the row is partly a result of a culture clash between the business-oriented Walter and the scientists. "The 'bottom-line' priorities for the scientists are matters such as publications in highimpact journals," he says, whereas the board is more focused on financial factors that "have to be balanced with the science priorities".

"What Australia hasn't realized is that it is trying to get an international scientific project to work," adds SAC member Michael Grunze of the University of Heidelberg in Germany. "It's not just a synchrotron issue. It's about trust, faith and the ability to manage big science facilities."
The synchrotron began operating in July 2007, and soon hosted more than 1,000 users on its nine beamlines. In the past 2 years, it has catered to scientists from almost 50 institutions in Australia and overseas, who use the synchrotron's intense light to study, for example, nanomaterials and proteins. Its

"No synchrotron Aus\$221-million director has (US\$201 million) cost was funded by an been removed unusual combination from office without the state of Victoria, of the government of the state of Victoria New Zealand federal governments, universities and other institutions. It is governed by a board of seven people, including Walter.

According to scientists on the SAC, Walter has routinely ignored advice given by the committee, particularly about the need to begin securing funding for after 2012, says Grunze. "In the first year we never even got a reply recognizing that our recommendations had been received," he says. The SAC recommended in May 2008 that the synchrotron should begin working on a new 5-year funding plan that would raise Aus $\$ 250$ million. "Raising that much money is not easy," says Larkins. "You need to build a consensus on what the money should be spent on and what science you need to do. We advised the board accordingly, but the chair took no significant action." Walter says that the SAC "assists the board on scientific matters. It does not have governance responsibility."

The situation became critical in late October when the facility director, chemist Robert Lamb of the University of Melbourne, was dismissed without explanation, Lamb says. "We were doing extremely well," he says. "We were running just below budget, had raised a considerable amount of 
faculty members, the biggest upset is not the decision itself but the fact that it was made without consulting them.

Veterinary researcher Richard Eberle, who was an administrative liaison for the study, believes that the affair might give the impression that the university is no longer a reliable research partner. He notes that two major proposals for OSU-based primate research, involving some of the same institutions, are pending at the NIH. The NIH Office of the Director said in a statement that institutions are expected "to complete NIH supported projects as requested, approved and funded".

The dispute comes during a time of heightened activity by animal-rights activists, including firebombings at two University of California campuses. Although few institutions have policies that prohibit primate research, not many are keen to establish new primate programmes, says Dario Ringach, a neurobiologist at the University of California, Los Angeles, who stopped working on primates because of pressure from activists. "It is changing the kind of work people will do in the future," he says. "If students come to me interested in primate research, I would tell them to think about other things."

Brendan Borrell

See Editorial, page 699.

money and were very popular with the national and international scientific user communities."

Walter says that legal and confidentiality issues prevent the board from disclosing the details of Lamb's sacking. "The board unanimously resolved this course of action for a number of reasons that included significant compliance and stakeholder relationship issues which had built up over the past year," she says. The synchrotron has secured operational funding until June 2012 and is working on plans for further expansion, she adds.

So far, neither the Victorian nor the national governments have intervened, saying that it is a matter for the board to resolve. Angry at this lack of action, the scientists and technicians at the synchrotron began limiting their work to 9 a.m. to 5 p.m. in late November, a crippling move for a facility that is booked to run 24 hours a day. Although they returned to normal schedules after Walter agreed to discuss their complaints, they now say that they will again work to rule unless Walter leaves.

The SAC has written to Victorian premier John Brumby protesting against Lamb's dismissal: "In our collective experience spanning decades and continents, no synchrotron director has ever been removed from office without notice."

Stephen Pincock

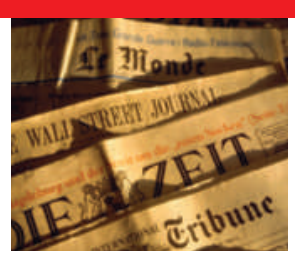

GOT ANEWS TIP?

Send any article ideas for Nature's News section to newstips@nature.com

\section{'Killer application' for protein synthesis is retracted}

The retraction of two papers from the lab of prominent US chemist Peter Schultz is a setback for researchers trying to synthesize and study glycoproteins proteins with sugar chains attached.

The papers, published in Science ${ }^{1}$ and the Journal of the American Chemical Society $^{2}$ (JACS), seemed to show that technology enabling the bacterium Escherichia coli to make proteins from many non-natural amino acids could also incorporate sugars at specific sites.

Schultz, of the Scripps Research Institute in La Jolla, California, says that while attempting to replicate the work in the two papers, members of his lab discovered that non-natural glycosylated amino acids - ones with attached sugars - behave differently from all other non-natural amino acids his lab has studied. The researchers were unable to get the specific amino acids described in the two papers to integrate into proteins, although they did manage to get the bacteria to make proteins incorporating other glycosylated amino acids, Schultz says. He and his colleagues retracted the JACS paper on 4 September ${ }^{3}$ and the Science paper on 27 November ${ }^{4}$.

In August, a paper co-authored by Eric Tippmann, a former postdoc of Schultz's who is now at Cardiff University, UK, argued that the method described in the papers could not have worked anyway ${ }^{5}$. E. coli, he reported, has insufficient levels of the relevant enzymes necessary to process the glycosylated amino acids that were used in the experiment. He and his colleagues suggest ${ }^{5}$ that the proteins reported in the retracted papers contained natural rather than non-natural glycosylated amino acids.

Schultz says it could be true that the proteins incorporated natural rather than non-natural amino acids, but adds that there are other possible explanations for his results.

He says that the conditions of the original experiments may have allowed the E. coli to process the glycosylated amino acids, which had been modified to allow them to enter the bacteria easily. However, the lab no longer has the notebooks detailing the original experiments, so the team can't replicate those conditions, Schultz explains.

Schultz says that he had members of his lab try to replicate the papers for more than two years. "We worked hard on it, and there are real peculiarities associated with the glycosylated amino acids that we still don't understand," Schultz says. "We couldn't get it to work." Only then did the team decide to retract the papers. "I think we did the right thing," says Schultz.

Glycoproteins are ubiquitous in biology and pharmacology, but difficult to make artificially in living cell systems, so the ability to direct bacteria to make specific glycoproteins would have been a boon.

Chemist David Tirrell of the California Institute of Technology in Pasadena, who also studies methods for incorporating non-natural amino acids into proteins, says the retractions will be a blow for glycobiologists. But because the glycobiology work was often seen as proof of principle, it is also a disappointment for anyone working on making proteins from non-natural amino acids, he says. "This

akes away one of the benchmarks people would cite to show how far the method could go," says Tirrell.

Another former postdoc of Schultz's, Ryan Mehl, who is now at Franklin \& Marshall College in Lancaster, Pennsylvania, agrees. "[Glycobiologists] went from something where they had the potential for great tools to zero, so it's a big deal for that field."

Schultz's underlying method for incorporating non-natural amino acids into proteins has been reproduced by other labs, note Tirrell, Mehl and other scientists. But the ability to incorporate glycoproteins "would have been a killer application", says Steven Benner of the Foundation for Applied Molecular Evolution in Gainesville, Florida. "I'm disappointed that it didn't work." Erika Check Hayden

\footnotetext{
. Zhang, Z. et al. Science 303, 371-373 (2004).

2. Xu, R. et al. J. Am. Chem. Soc. 126, 15654-15655 (2004).

Xu, R. et al. J. Am. Chem. Soc. 131, 13883 (2009)

4. Zhang, Z. et al. Science 326, 1187 (2009).

5. Antonczak, A. K., Simova, Z. \& Tippmann, E. M. J. Biol. Chem. 284, 28795-28800 (2009).
} 